RESEARCH ARTICLE

\title{
Quality attributes and phytochemical properties of fresh juice produced from selected mango varieties
}

\author{
G.O. Babarinde ${ }^{1, *}$, S.J. Olatunde ${ }^{1}$ and A. Adebiyi-Olabode ${ }^{1}$
}

${ }^{1}$ Department of Food Science and Engineering, Ladoke Akintola University of Technology, Ogbomoso, Nigeria

Received: 03/04/2018; Accepted: 08/12/2018

\begin{abstract}
Mango (Mangifera indica L.) is a seasonal and highly perishable yet nutritious fruit with different varieties. Further, processing of the fruit will extend the shelf life and increase the potentials of exploiting the underutilized varieties. This paper investigated the suitability of four Nigerian mango varieties (Lippen, Kent, Palmer and Saigon) for fresh juice production and also evaluated the quality attributes of the stored juice samples. Well ripen, firm mango fruits were processed into juice, packed and stored at room temperature $\left(28 \pm 2^{\circ} \mathrm{C}\right)$. Selected chemical (titratable acidity, $\mathrm{pH}$, brix, ascorbic acid) and phytochemical (saponin, phytates and tannins) properties were determined. Sensory attributes of fresh juice were evaluated. All determinations were done in triplicates and data were subjected to analysis of variance using SPSS. Samples were tested in 4-day intervals till 24 days post juice production. Juice obtained from Kent variety had the least titratable acidity $(7.83 \pm 0.2 \mathrm{mg} / 100$ g), $\mathrm{pH}(4.41 \pm 0.2 \mathrm{mg} / 100 \mathrm{~g})$, brix $(11.83 \pm 0.2 \mathrm{mg} / 100 \mathrm{~g})$ while Lippen had highest values of titratable acidity $(10.23 \pm 0.2 \mathrm{mg} / 100$ $\mathrm{g}), \mathrm{pH}(5.27 \pm 0.0)$ and brix $(14.73 \pm 0.1 \mathrm{mg} / 100 \mathrm{~g})$ after 24 days of storage. Ascorbic acid content was highest $(12.10 \pm 0.0 \mathrm{mg} / 100$ $\mathrm{ml})$ in Lippen juice while least value $(9.40 \pm 0.3 \mathrm{mg} / 100 \mathrm{ml})$ was observed in Saigon juice. Ascorbic acid contents of juices decreased as storage period progressed. Saponin and phytate were present in all samples and decreased with increased storage time while tannin was constant from day 16 to 24 . Saigon juice was the most preferred of all the tested juice samples in terms of overall acceptability when evaluated for sensory properties.
\end{abstract}

Keywords: Mango varieties, juice, phytochemical attributes, storage.

\section{INTRODUCTION}

Fruits and vegetables are rich sources of nutrients with a lot of potential health benefits in preventing several chronic diseases (Slavin and Lloyd, 2012). Mango (Mangifera indica L.) is one of the three commonly grown horticultural tropical fruits (banana, mango and citrus), and these three contribute about $70 \%$ of the total fruit production in the world (Goswami et al., 2015). It ranks third among the tropical fruits grown with a total production of 23.87 million tons (FAO, 2006). Mango is one of the majorly cultivated fruits in Nigeria, but the production is seasonal. Its peak production season is usually between April and June every year (Adelakun et al., 2013). Mango fruit is fleshy, sweet when fully ripe but slightly acidic when green. The fruit varies considerably in size, shape, colour, flavour, and composition (FAO, 2002). It is often consumed fresh or processed into various products such as fruit juice, purees, jams, fruit salads, dried fruits, chutney and snacks (Singh et al., 2000). Mango pulp is widely utilized for both domestic and industrial purposes (Masibo and He, 2009). The texture of the flesh varies markedly among different cultivars; some have a very firm flesh and other cultivars may be fibrous.

Mango is an excellent source of fibre and antioxidants such as provitamin A carotenoids, vitamin $\mathrm{C}$ and phenolics (Gouado et al., 2007; Lemmens et al., 2013). Fowomola (2010) reported that mango is rich in a variety of phytochemicals and nutrients that qualifies it as a "superfruit", a term used to describe potential health content of some nutritious fruits. Its yellow-orange characteristic colour is due to the presence of carotenoids. Phytochemical compounds possess curative properties associated with presence of various secondary metabolites which are non-nutritive plant compounds (Babajide et al., 2013). Mango contains about $83 \%$ water, carbohydrates and minerals such as calcium, iron and potassium (Leghari et al., 2013). Its nutritional content is affected by factors such as cultivar, growing conditions, stage of maturity, storage and processing conditions (Lee and Kader, 2000).

Apart from its seasonal availability, it has a relatively short postharvest shelf life due to its high perishability. In Nigeria, there are different varieties of mango with different tastes, colours and flavours which influence their suitability and acceptability for juice production. The potentials of some of these varieties for juice production have not been fully explored and their behaviour during storage has not been fully studied. It is therefore important to evaluate the influence of varietal differences on the keeping qualities of juice during storage. Storage at room temperature can affect chemical composition and sensory properties of different mango varieties. Incidentally, information is sparse on comparative changes that occur in juice produced from different mango cultivars during storage. This research therefore aimed at investigating some qualities attributes and phytochemical properties of juice produced from four Nigerian mango varieties during storage period. 


\section{MATERIAL AND METHODS}

\section{Raw materials selection and preparation of mango juice samples}

Four fully matured Nigerian mango varieties (Lippen, Kent, Palmer and Saigon) that were ripe with no blemish were obtained from Nigeria Institute of Horticultural Research (NIHORT) Jericho, Ibadan, Nigeria. The mango fruits were washed with clean distilled water, manually peeled, pitted and the flesh was cut into small pieces $(1.0-1.5 \mathrm{~cm}$ thick, $3.0-5.0 \mathrm{~cm}$ long). The pulp was loaded into a Kenwood juice processor (Model FP691) to extract juice according to the method of Adelakun et al. (2013). Fruit juices were pasteurized at $85^{\circ} \mathrm{C}$ for 10 minutes, stored at $28 \pm 2^{\circ} \mathrm{C}$ and taken for analysis after every four-day intervals until 24 days. All the readings were taken in triplicates.

\section{Chemical and phytochemical analyses}

The $\mathrm{pH}$ values were measured using a Jenway Model P107 $\mathrm{pH}$ meter. The titratable acidity was determined according to the method earlier described by Nielsen (1998). Fresh mango juice $(10 \mathrm{ml})$ was dispensed in a conical flask and two drops of phenolphthalein indicator was added. It was then titrated with $0.1 \mathrm{~N} \mathrm{NaOH}$ solutions till a permanent pink colour appeared. The volume of $\mathrm{NaOH}$ solution required for titration was recorded and percentage titratable acidity was calculated. Total soluble solids (TSS) were measured at $20^{\circ} \mathrm{C}$ using Abbe Refractometer Model, 2WAJ according to the method of AOAC (2005). Total solid (TS) was determined by the method described in AOAC (2005) with slight modification. For the estimation of TS, $10 \mathrm{ml}$ of mango juice was evaporated in an oven at $105^{\circ} \mathrm{C}$ and the solids left after evaporation was weighed and values for TS was calculated .

Ascorbic acid content was determined using 2, 6-dichlorophenol indophenol dye titration method described by AOAC (2005). Approximately $0.05 \mathrm{~g}$ of 2, 6- dichlorophenol indophenols was dissolved in water and diluted to $100 \mathrm{ml}$. Standard ascorbic acid was prepared by dissolving $0.05 \mathrm{~g}$ pure ascorbic acid in $60 \mathrm{ml}$ of $20 \%$ metaphosphoric acid and was diluted with water to exactly $250 \mathrm{ml}$ in a volumetric flask. Standard ascorbic acid solution $(10 \mathrm{ml})$ was pipetted in a flask and titrated with indophenols until a faint pink colour persisted for 15 seconds. The concentration was expressed as mg ascorbic acid equivalent to $1 \mathrm{ml}$ dye solution. Extracted juice (50 $\mathrm{ml}$ ) and $25 \mathrm{ml}$ of $20 \%$ metaphosphoric acid were mixed. The mixture $(10 \mathrm{ml})$ was withdrawn into a small flask and $2.5 \mathrm{ml}$ of acetone was added. This was titrated with indophenols solution until a faint pink colour persisted for 15 seconds. Vitamin $\mathrm{C}$ content of the samples was calculated using the formula.

$$
\text { Ascorbic acid }(\mathrm{mg} / 100 \mathrm{~g})=\frac{\text { Titre value } \times 0.212 \times 100}{\text { Weight of sample }}
$$

Tannin was determined using the AOAC (2005) method. One gram of juice sample was measured into a $50 \mathrm{ml}$ beaker and $2 \mathrm{ml}$ of $50 \%$ methanol was added and covered with paraffin and placed in a water bath at $77-80^{\circ} \mathrm{C}$ for 1 hour.
It was thoroughly shaken to ensure a uniform mixing. The extract was quantitatively filtered using a double layered Whatman No 4 filter paper in to a $100 \mathrm{ml}$ volumetric flask. The absorbance of the Tannic acid standard solution as well as the juice samples was read after colour development on a $21 \mathrm{D}$ spectrophotometer at a wave length of $760 \mathrm{~nm}$.

Saponin content was determined using the Brunner (1984) method. Finely ground sample (1 g) was weighed into $250 \mathrm{ml}$ beaker and $100 \mathrm{ml}$ of isobutyl alcohol was added. The absorbance of the samples as well as standard solutions was read in a Jenway V6300 spectrophotometer at a wavelength of $380 \mathrm{~nm}$. Phytate was determined using Maga (1982) method. Two grams of each juice sample was weighed into $250 \mathrm{ml}$ conical flask. Hydrochloric acid (2\% applied at $100 \mathrm{ml}$ ) was added to soak each sample in the conical flask for 3 hours. This was filtered through a double layer hardened filter paper. Each filtrate $(50 \mathrm{ml})$ was placed in $250 \mathrm{ml}$ conical flask and $100 \mathrm{ml}$ of distilled water was added into each solution as indicated. This was titrated with standard iron (III) chloride solution which contained $0.00195 \mathrm{~g}$ iron per $\mathrm{ml}$.

\section{Sensory evaluation}

A panel of 35 trained individuals, aged 18-40 years, who were regular consumers of mango juice, was constituted. The prepared mango juice was coded and served. Panellists were asked to evaluate taste, flavour, sweetness, colour and overall acceptability using 9 point hedonic scale where $1=$ dislike extremely; $4=$ neither like nor dislike and $9=$ like extremely (Ranganna, 2001).

\section{Statistical analysis}

Data obtained were subjected to analysis of variance (ANOVA). Means were separated using Duncan Multiple Range Test at 5\% probability level using a computer software package (SPSS, 2006).

\section{RESULTS AND DISCUSSION}

\section{Chemical properties of mango juice during storage}

The $\mathrm{pH}$ value of fresh mango juice samples ranged from $4.83 \pm 0.1$ to $5.58 \pm 0.3$. Lippen variety had the highest value $(5.58 \pm 0.3)$ while lowest value $(4.83 \pm 0.1)$ was observed in Kent juice (Table 1). A steady decrease was observed in the $\mathrm{pH}$ of all samples during storage and Kent juice had the $\mathrm{pH}$ value of 4.41 which was within standard $\mathrm{pH}(3.8$ - 5.6) value for fruit juice production (Ihekoronye and Ngoddy, 1985). The values obtained were within the range reported by Bibi and Baloch (2012) for stored coated mango. Baloch et al. (2013) reported lower $\mathrm{pH}$ of stored mango over a longer storage duration. The decrease in $\mathrm{pH}$ implies increase in acidity as a result of increase in hydrogen ions during storage (Akhtar et al., 2013). Although, the pH values obtained in this study were higher than the mean $\mathrm{pH}$ values of mango juices (4.04) reported by Londoño et al. (2017), the reason for the variation could be variability of the studied mango varieties.

The titratable acidity of the mango juice varied remarkably during storage (Table 1). The acidity increased 
Table 1: $\mathrm{pH}$ and titratable acidity $(\mathrm{mg} / 100 \mathrm{~g})$ contents of juice produced from four mango varieties during storage.

\begin{tabular}{|c|c|c|c|c|c|c|c|c|}
\hline \multirow{2}{*}{ Attributes } & \multirow{2}{*}{$\begin{array}{c}\text { Mango } \\
\text { varieties }\end{array}$} & \multicolumn{7}{|c|}{ Storage period (days) } \\
\hline & & 0 & 4 & 8 & 12 & 16 & 20 & 24 \\
\hline \multirow[t]{4}{*}{$\mathrm{pH}$} & Lippen & $5.58 \pm 0.3^{\mathrm{a}}$ & $5.50 \pm 0.0^{\mathrm{a}}$ & $5.42 \pm 0.2^{\mathrm{a}}$ & $5.36 \pm 0.0^{\mathrm{a}}$ & $5.32 \pm 0.1^{\mathrm{a}}$ & $5.29 \pm 0.0^{\mathrm{a}}$ & $5.27 \pm 0.0^{\mathrm{a}}$ \\
\hline & Palmer & $5.26 \pm 0.2^{b}$ & $5.24 \pm 0.2^{\mathrm{b}}$ & $5.13 \pm 0.3^{b}$ & $5.12 \pm 0.0^{\mathrm{b}}$ & $5.09 \pm 0.1^{\mathrm{b}}$ & $5.05 \pm 0.0^{\mathrm{a}}$ & $5.00 \pm 0.0^{\mathrm{b}}$ \\
\hline & Saigon & $5.03 \pm 0.2^{\mathrm{b}}$ & $4.97 \pm 0.3^{\mathrm{c}}$ & $4.95 \pm 0.2^{\mathrm{c}}$ & $4.87 \pm 0.3^{c}$ & $4.79 \pm 0.2^{\mathrm{c}}$ & $4.76 \pm 0.0^{c}$ & $4.75 \pm 0.1^{\mathrm{c}}$ \\
\hline & Kent & $4.83 \pm 0.1^{\mathrm{c}}$ & $4.70 \pm 0.2^{\mathrm{d}}$ & $4.56 \pm 0.3^{\mathrm{d}}$ & $4.53 \pm 0.2^{\mathrm{d}}$ & $4.50 \pm 0.1^{\mathrm{d}}$ & $4.45 \pm 0.3^{\mathrm{d}}$ & $4.41 \pm 0.2^{\mathrm{d}}$ \\
\hline \multirow[t]{4}{*}{$\begin{array}{l}\text { Titratable } \\
\text { acidity }\end{array}$} & Lippen & $9.17 \pm 0.0^{\mathrm{a}}$ & $9.37 \pm 0.2^{\mathrm{a}}$ & $9.83 \pm 0.1^{\mathrm{a}}$ & $9.97 \pm 0.1^{\mathrm{a}}$ & $10.00 \pm 0.0^{\mathrm{a}}$ & $10.20 \pm 0.1^{\mathrm{a}}$ & $10.23 \pm 0.2^{a}$ \\
\hline & Palmer & $9.10 \pm 0.0^{\mathrm{a}}$ & $9.37 \pm 0.2^{\mathrm{a}}$ & $9.57 \pm 0.0^{\mathrm{b}}$ & $9.90 \pm 0.1^{\mathrm{a}}$ & $10.03 \pm 0.0^{\mathrm{a}}$ & $10.13 \pm 0.2^{\mathrm{a}}$ & $10.20 \pm 0.2$ \\
\hline & Saigon & $8.33 \pm 0.2^{b}$ & $8.50 \pm 0.1^{b}$ & $8.77 \pm 0.2^{c}$ & $8.93 \pm 0.0^{\mathrm{b}}$ & $9.10 \pm 0.1^{\mathrm{b}}$ & $9.13 \pm 0.1^{\mathrm{b}}$ & $9.27 \pm 0.3^{\mathrm{b}}$ \\
\hline & Kent & $6.60 \pm 0.4^{\mathrm{c}}$ & $6.97 \pm 0.3^{\mathrm{c}}$ & $7.10 \pm 0.2^{\mathrm{d}}$ & $7.33 \pm 0.2^{\mathrm{c}}$ & $7.68 \pm 0.2^{\mathrm{c}}$ & $7.77 \pm 0.2^{\mathrm{c}}$ & $7.83 \pm 0.2^{\mathrm{c}}$ \\
\hline
\end{tabular}

Means with the same superscript along the column are not significantly different $(\mathrm{p}>0.05)$; \pm standard deviation

Table 2: Total soluble solids ( ${ }^{\circ}$ brix) and total solids (\%) of juice produced from four mango varieties during storage.

\begin{tabular}{|c|c|c|c|c|c|c|c|c|}
\hline \multirow{2}{*}{ Attributes } & \multirow{2}{*}{$\begin{array}{c}\text { Mango } \\
\text { varieties }\end{array}$} & \multicolumn{7}{|c|}{ Storage period (days) } \\
\hline & & $\mathbf{0}$ & 4 & 8 & 12 & 16 & 20 & 24 \\
\hline \multirow[t]{4}{*}{$\begin{array}{l}\text { Total Soluble } \\
\text { Solids (' }{ }^{\circ} \text { brix) }\end{array}$} & Lippen & $14.30 \pm 0.2^{\mathrm{a}}$ & $14.53 \pm 0.1^{\mathrm{a}}$ & $14.53 \pm 0.1^{\mathrm{a}}$ & $14.60 \pm 0.1^{\mathrm{a}}$ & $14.67 \pm 0.0^{\mathrm{a}}$ & $14.70 \pm 0.3^{\mathrm{a}}$ & $14.73 \pm 0.1^{\mathrm{a}}$ \\
\hline & Palmer & $13.50 \pm 0.1^{\mathrm{b}}$ & $13.43 \pm 0.1^{\mathrm{b}}$ & $13.60 \pm 0.2^{\mathrm{b}}$ & $13.70 \pm 0.1^{\mathrm{b}}$ & $13.73 \pm 0.0^{\mathrm{b}}$ & $13.77 \pm 0.2^{\mathrm{b}}$ & $13.87 \pm 0.0^{\mathrm{b}}$ \\
\hline & Saigon & $12.20 \pm 0.2^{\mathrm{c}}$ & $12.47 \pm 0.0^{c}$ & $12.50 \pm 0.1^{\mathrm{c}}$ & $12.57 \pm 0.1^{\mathrm{c}}$ & $12.53 \pm 0.3^{\mathrm{c}}$ & $12.60 \pm 0.1^{\mathrm{c}}$ & $12.77 \pm 0.2^{\mathrm{c}}$ \\
\hline & Kent & $11.50 \pm 0.2^{\mathrm{d}}$ & $11.60 \pm 0.0^{\mathrm{d}}$ & $11.73 \pm 0.4^{\mathrm{d}}$ & $11.77 \pm 0.2^{\mathrm{d}}$ & $11.80 \pm 0.2^{\mathrm{d}}$ & $11.80 \pm 0.2^{\mathrm{d}}$ & $11.83 \pm 0.2^{\mathrm{d}}$ \\
\hline \multirow[t]{4}{*}{$\begin{array}{l}\text { Total Solids } \\
(\%)\end{array}$} & Lippen & $16.50 \pm 0.0^{\mathrm{a}}$ & $16.67 \pm 0.1^{\mathrm{a}}$ & $16.80 \pm 0.2^{\mathrm{a}}$ & $16.83 \pm 0.2^{\mathrm{a}}$ & $16.97 \pm 0.0^{\mathrm{a}}$ & $16.97 \pm 0.1^{\mathrm{a}}$ & $17.03 \pm 0.1^{\mathrm{a}}$ \\
\hline & Palmer & $15.33 \pm 0.2^{\mathrm{b}}$ & $15.63 \pm 0.0^{\mathrm{b}}$ & $15.77 \pm 0.1^{\mathrm{b}}$ & $15.80 \pm 0.1^{\mathrm{b}}$ & $15.80 \pm 0.3^{\mathrm{b}}$ & $15.83 \pm 0.3^{\mathrm{b}}$ & $15.63 \pm 0.1^{\mathrm{b}}$ \\
\hline & Saigon & $14.53 \pm 0.2^{\mathrm{c}}$ & $14.90 \pm 0.0^{c}$ & $15.07 \pm 0.2^{\mathrm{c}}$ & $15.27 \pm 0.1^{\mathrm{c}}$ & $15.27 \pm 0.2^{\mathrm{c}}$ & $15.57 \pm 0.2^{\mathrm{c}}$ & $15.60 \pm 0.1^{\mathrm{b}}$ \\
\hline & Kent & $13.33 \pm 0.4^{\mathrm{d}}$ & $13.47 \pm 0.3^{\mathrm{d}}$ & $13.63 \pm 0.1^{\mathrm{d}}$ & $13.70 \pm 0.3^{\mathrm{d}}$ & $13.70 \pm 0.2^{\mathrm{d}}$ & $13.37 \pm 0.3^{\mathrm{d}}$ & $13.40 \pm 0.1^{\mathrm{d}}$ \\
\hline
\end{tabular}

Means with the same superscript along the column are not significantly different $(\mathrm{p}>0.05) ; \pm$ standard deviation

during storage for all the varieties; juice extracted from Lippen and Palmer had the highest titratable acidity which ranged between $9.17 \pm 0.0$ and $10.23 \pm 0.2 \mathrm{mg} / 100 \mathrm{ml}$. The increase could be due to partial hydrolysis of organic acid as reported by Elsheikh et al. (2014). There were variations in TSS of all juice samples produced from all mango varieties which were significantly $(p<0.05)$ different. Values obtained from samples prior to storage ranged from $11.50 \pm 0.2$ to $14.30 \pm 0.2^{\circ}$ brix (Table 2) and as the storage period progresses, TSS values for all samples increased. The lowest value of TSS was recorded in Kent juice which has the values $11.50 \pm 0.2-11.83 \pm 0.2^{\circ}$ brix from day 0 to 24. Baloch and Bibi (2012) also reported trend similar. Trend similar to what was obtained in this study which revealed that TSS increased with the ripening process and storage time and high storage temperature gave higher TSS irrespective of the fruit variety. Increase in TSS could be due to conversion of carbohydrates into simple sugars during storage; the higher the storage temperature, the higher the conversion rate (Islam et al., 2013).

The TS contents of the juice samples produced from the four mango varieties ranged between $13.33 \pm 0.4$ and $16.50 \pm 0.0 \%$ on day 0 (i.e. soon after preparation) (Table 2). Lippen juice had the highest value of total solid content followed by Palmer which was significantly $(p<0.05)$ different from juice extracted from other mango varieties. TS contents increased with storage duration for all the samples, with Lippen having the highest value (17.03 $\pm 0.1 \%$ ) compared with other varieties (13.40 $\pm 0.1-15.60$ $\pm 0.1 \%$ ) after 24 days of storage (Table 2 ). The ascorbic acid contents of the juice samples ranged from $20.17 \pm 0.5$ to $27.57 \pm 0.2 \mathrm{mg} / 100 \mathrm{ml}$ (Table 3), while Lippen juice had the significantly $(\mathrm{p}<0.05)$ highest value of vitamin $\mathrm{C}$ $(27.57 \pm 0.2 \mathrm{mg} / 100 \mathrm{ml})$ compared with the values for other juice samples $(20.17 \pm 0.5-25.49 \pm 0.2 \mathrm{mg} / 100 \mathrm{ml})$ on day 0 . Ascorbic acid contents decreased during storage for all the juice samples but Lippen juice had higher ascorbic acid content throughout the storage period. This was due to varietal differences. Wilson et al. (2014) reported that storage temperature can affect vitamin $\mathrm{C}$ contents of fruits, while Uddin et al. (2002) reported that as the storage time and temperature increased, ascorbic acid content decreased in dried guava samples. Kårlund et al. (2014) suggested that storage conditions must be evaluated individually for each fruit cultivar to preserve vitamin $\mathrm{C}$. Those varieties that are sensitive to vitamin $C$ degradation could therefore be subjected to different modified storage atmosphere or to customized packaging in order to diminish losses. 
Table 3: Ascorbic acid contents $(\mathrm{mg} / 100 \mathrm{ml})$ of juice produced from four mango varieties during storage.

\begin{tabular}{lccccccc}
\hline Mango & \multicolumn{7}{c}{ Storage period (days) } \\
\cline { 2 - 8 } Varieties & $\mathbf{0}$ & $\mathbf{4}$ & $\mathbf{8}$ & $\mathbf{1 2}$ & $\mathbf{1 6}$ & $\mathbf{2 0}$ & $\mathbf{2 4}$ \\
\hline Lippen & $27.57 \pm 0.2^{\mathrm{a}}$ & $24.00 \pm 0.0^{\mathrm{a}}$ & $23.00 \pm 0.1^{\mathrm{a}}$ & $20.43 \pm 0.1^{\mathrm{a}}$ & $18.43 \pm 0.2^{\mathrm{a}}$ & $16.10 \pm 0.2^{\mathrm{a}}$ & $12.10 \pm 0.0^{\mathrm{a}}$ \\
Palmer & $25.49 \pm 0.2^{\mathrm{b}}$ & $21.90 \pm 0.3^{\mathrm{c}}$ & $21.33 \pm 0.1^{\mathrm{b}}$ & $17.33 \pm 0.3^{\mathrm{c}}$ & $14.33 \pm 0.0^{\mathrm{b}}$ & $12.33 \pm 0.2^{\mathrm{b}}$ & $10.17 \pm 0.0^{\mathrm{b}}$ \\
Saigon & $25.23 \pm 0.1^{\mathrm{b}}$ & $22.57 \pm 0.2^{\mathrm{b}}$ & $20.33 \pm 0.1^{\mathrm{c}}$ & $18.33 \pm 0.2^{\mathrm{b}}$ & $12.00 \pm 0.5^{\mathrm{c}}$ & $10.00 \pm 0.2^{\mathrm{c}}$ & $9.40 \pm 0.3^{\mathrm{c}}$ \\
Kent & $20.17 \pm 0.5^{\mathrm{c}}$ & $18.17 \pm 0.3^{\mathrm{d}}$ & $12.60 \pm 1.1^{\mathrm{d}}$ & $12.60 \pm 0.3^{\mathrm{d}}$ & $10.83 \pm 0.0^{\mathrm{d}}$ & $9.67 \pm 0.2^{\mathrm{c}}$ & $9.60 \pm 0.3^{\mathrm{c}}$ \\
\hline
\end{tabular}

Means with the same alphabet along the column are not significantly different $(\mathrm{p}>0.05) ; \pm$ standard deviation

Table 4: Phytochemical properties $(\mathrm{mg} / 100 \mathrm{ml})$ of juice produced from four mango varieties during storage.

\begin{tabular}{lllllllll}
\hline \multirow{2}{*}{ Parameters } & Mango & \multicolumn{7}{c}{ Storage period (days) } \\
\cline { 3 - 8 } & varieties & 0 & 4 & 8 & 12 & 16 & 20 & 24 \\
\hline Tannins & Palmer & $15.17 \pm 0.2^{\mathrm{a}}$ & $14.50 \pm 0.3^{\mathrm{a}}$ & $14.33 \pm 0.1^{\mathrm{a}}$ & $14.33 \pm 0.1^{\mathrm{a}}$ & $14.00 \pm 0.0^{\mathrm{a}}$ & $14.00 \pm 0.3^{\mathrm{a}}$ & $14.00 \pm 0.3^{\mathrm{a}}$ \\
& Lippen & $12.67 \pm 0.2^{\mathrm{b}}$ & $12.33 \pm 0.1^{\mathrm{a}}$ & $12.00 \pm 0.1^{\mathrm{b}}$ & $12.83 \pm 0.3^{\mathrm{b}}$ & $11.67 \pm 0.1^{\mathrm{b}}$ & $11.33 \pm 0.0^{\mathrm{b}}$ & $11.33 \pm 0.2^{\mathrm{b}}$ \\
& Kent & $10.00 \pm 0.0^{\mathrm{c}}$ & $9.83 \pm 0.0^{\mathrm{d}}$ & $10.00 \pm 0.0^{\mathrm{c}}$ & $9.83 \pm 0.2^{\mathrm{c}}$ & $9.83 \pm 0.3^{\mathrm{c}}$ & $9.67 \pm 0.4^{\mathrm{c}}$ & $9.50 \pm 0.2^{\mathrm{c}}$ \\
& Saigon & $8.00 \pm 0.0^{\mathrm{d}}$ & $8.00 \pm 0.0^{\mathrm{c}}$ & $7.83 \pm 0.3^{\mathrm{d}}$ & $7.67 \pm 0.2^{\mathrm{d}}$ & $7.67 \pm 0.3^{\mathrm{d}}$ & $7.67 \pm 0.2^{\mathrm{d}}$ & $7.67 \pm 0.1^{\mathrm{d}}$ \\
\multirow{3}{*}{ Phytate } & Palmer & $7.50 \pm 0.5^{\mathrm{a}}$ & $7.33 \pm 0.1^{\mathrm{a}}$ & $7.17 \pm 0.1^{\mathrm{a}}$ & $7.17 \pm 0.3^{\mathrm{a}}$ & $7.17 \pm 0.2^{\mathrm{a}}$ & $7.17 \pm 0.1^{\mathrm{a}}$ & $7.17 \pm 0.0^{\mathrm{a}}$ \\
& Lippen & $6.33 \pm 0.0^{\mathrm{b}}$ & $6.17 \pm 0.2^{\mathrm{b}}$ & $6.50 \pm 0.3^{\mathrm{b}}$ & $6.50 \pm 0.2^{\mathrm{b}}$ & $6.50 \pm 0.1^{\mathrm{b}}$ & $6.50 \pm 0.2^{\mathrm{b}}$ & $6.50 \pm 0.3^{\mathrm{b}}$ \\
& Kent & $5.00 \pm 0.0^{\mathrm{c}}$ & $5.00 \pm 0.3^{\mathrm{c}}$ & $5.00 \pm 0.2^{\mathrm{c}}$ & $5.00 \pm 0.0^{\mathrm{c}}$ & $5.00 \pm 0.0^{\mathrm{c}}$ & $5.00 \pm 0.0^{\mathrm{c}}$ & $5.00 \pm 0.2^{\mathrm{c}}$ \\
& Saigon & $3.67 \pm 0.1^{\mathrm{d}}$ & $3.83 \pm 0.2^{\mathrm{d}}$ & $4.00 \pm 0.0^{\mathrm{d}}$ & $4.00 \pm 0.1^{\mathrm{d}}$ & $4.00 \pm 0.0^{\mathrm{d}}$ & $4.00 \pm 0.0^{\mathrm{d}}$ & $4.00 \pm 0.3^{\mathrm{d}}$ \\
& Palmer & $18.00 \pm 0.5^{\mathrm{a}}$ & $18.00 \pm 0.1^{\mathrm{a}}$ & $18.00 \pm 0.2^{\mathrm{a}}$ & $18.00 \pm 0.7^{\mathrm{a}}$ & $18.00 \pm 0.1^{\mathrm{a}}$ & $18.00 \pm 0.1^{\mathrm{a}}$ & $18.00 \pm 1.0^{\mathrm{a}}$ \\
& Lippen & $16.00 \pm 0.3^{\mathrm{b}}$ & $16.67 \pm 0.0^{\mathrm{b}}$ & $15.00 \pm 0.1^{\mathrm{b}}$ & $14.83 \pm 0.3^{\mathrm{b}}$ & $14.67 \pm 0.2^{\mathrm{b}}$ & $14.50 \pm 0.3^{\mathrm{b}}$ & $14.50 \pm 0.3^{\mathrm{b}}$ \\
& Kent & $14.00 \pm 0.2^{\mathrm{c}}$ & $14.00 \pm 0.2^{\mathrm{c}}$ & $13.67 \pm 0.2^{\mathrm{c}}$ & $13.50 \pm 0.2^{\mathrm{c}}$ & $13.50 \pm 0.5^{\mathrm{c}}$ & $13.50 \pm 0.2^{\mathrm{c}}$ & $13.50 \pm 0.2^{\mathrm{c}}$ \\
& Saigon & $12.00 \pm 0.7^{\mathrm{d}}$ & $11.83 \pm 0.3^{\mathrm{d}}$ & $11.67 \pm 0.4^{\mathrm{d}}$ & $11.67 \pm 0.3^{\mathrm{d}}$ & $11.50 \pm 0.1^{\mathrm{d}}$ & $11.50 \pm 0.3^{\mathrm{d}}$ & $11.50 \pm 0.1^{\mathrm{d}}$ \\
\hline
\end{tabular}

Table 5: Sensory attributes of juice produced from four mango varieties during storage.

\begin{tabular}{lllll}
\hline & \multicolumn{4}{c}{ Quality attributes } \\
\hline Mango varieties & Colour & Taste & Sweetness & Overall acceptability \\
\hline Saigon & $6.29 \pm 0.3^{\mathrm{a}}$ & $6.81 \pm 0.0^{\mathrm{a}}$ & $6.61 \pm 0.3^{\mathrm{a}}$ & $6.74 \pm 0.6^{\mathrm{a}}$ \\
Palmer & $6.26 \pm 0.4^{\mathrm{a}}$ & $6.49 \pm 0.2^{\mathrm{ab}}$ & $6.39 \pm 0.6^{\mathrm{b}}$ & $6.52 \pm 0.5^{\mathrm{b}}$ \\
Kent & $6.35 \pm 0.2^{\mathrm{a}}$ & $6.45 \pm 0.3^{\mathrm{b}}$ & $6.03 \pm 0.5^{\mathrm{b}}$ & $6.26 \pm 0.3^{\mathrm{b}}$ \\
Lippen & $6.00 \pm 0.4^{\mathrm{a}}$ & $6.45 \pm 0.5^{\mathrm{b}}$ & $6.22 \pm 0.2^{\mathrm{b}}$ & $6.32 \pm 0.2^{\mathrm{b}}$ \\
\hline
\end{tabular}

Means with the same superscript along the column are not significantly different $(\mathrm{p}>0.05) ; \pm$ standard deviation

\section{Phytochemical properties of mango juice during storage}

The results of phytochemical analysis (Table 4) showed that freshly produced mango juice contained tannins $(8.00$ \pm 0.0 - $15.17 \pm 0.2 \mathrm{mg} / 100 \mathrm{~g})$; phytate $(3.67 \pm 0.1-7.50 \pm 0.5$ $\mathrm{mg} / 100 \mathrm{~g})$ and saponins $(12.00 \pm 0.7-18.00 \pm 0.5 \mathrm{mg} / 100$ g). Tannin content decreased as storage time increased, except in Palmer and Saigon juices where tannins remained constant from day 16 to 24 . Tannins are aromatic compound containing phenolic groups and important in foods for their sensory attributes such as colour, astringency, and bitterness (Alaka et al., 2003). Tannin possessed a stringent property that helps in healing of wounds and inflamed mucous membranes (Okwu, 2004) and can inhibit the formation of superoxide radicals due to its antioxidative property (Chung et al., 1998). Palmer juice had the highest phytate value while the Saigon juice had the lowest value.
Generally, there was decrease in the trend of phytate during the storage of mango juice from day 0 to day 24. Saponin values decreased with increased storage time from day 0 to day 24. Saponins have been shown to possess cholesterol lowering properties, which makes it beneficial to humans (Price et al., 1987).

\section{Sensory evaluation}

The mean sensory scores (Table 5) showed significant differences among the quality attributes evaluated for the mango juice samples. Saigon juice was the most preferred in terms of taste, sweetness and overall acceptability, but other samples were not significantly different in terms of overall acceptability. There was no significant difference in rating of colour for all samples. 


\section{CONCLUSIONS}

This study has shown that total soluble solids, $\mathrm{pH}$ and vitamin $\mathrm{C}$ contents were highest in juice produced from Lippen variety. Tannin, phytate and saponin were present in all the mango juice samples and decreased with increase in storage period. The taste, sweetness and overall acceptability were best for juice produced from Saigon mango variety as compared with other juice samples. Storage period had pronounced effect on the quality of juice produced from the four mango varieties. Production of juice from mango varieties will minimize postharvest losses of these varieties when there is mango glut.

\section{REFERENCES}

Adelakun, O.E., Metcalfe, D., Tshabalala, P., Stafford, B. and Oni, B. (2013): The effect of pectinase enzyme on some quality attributes of a Nigerian mango juice. Nutrition and Food Science 43(4): 374-383.

AOAC. (2005). Official Methods of Analysis of AOAC International, $18^{\text {th }} \mathrm{ed}$. AOAC International, Gaithersburg, Maryland, USA.

Akhtar S., Javid, A., Bilal, J. and Ali, K.F. (2013). Studies on preparation and storage stability of pomengranate juice based drink. Middle East Journal of Scientific Research 16(2): 191-195.

Alaka, O.O., Aina, J.O. and Falade, K.O. (2003): Effect of storage conditions on the chemical attributes of Ogbomoso mango juice. European Journal of Food Research and Technology 218: 79-82.

Babajide, J.M., Olaluwoye, A.A. Shittu, T.A. and Adebisi, M.A. (2013). Physicochemical properties and phytochemical components of spiced cucumber pineapple fruit drink. Nigerian Food Journal 31: 40-52.

Baloch, M.K., Bibi, F. and Jilani, M.S. (2013). Effect of coatings over the quality and shelf life of mango (Mangifera indica L.) fruit. Journal of Food Processing and Preservation 37(1):66-73.

Bibi, F. and Baloch, M.K. (2012). Postharvest quality and shelf life of mango (Mangifera indica L.) fruit as affected by various coatings. Journal of Food Processing and Preservation 38: 499-507.

Brunner, J.H. (1984). Direct spectrophotometer determination of Saponin. Analytical Chemistry 34:1314-1326.

Chung, K., Wong, T.Y., Wei, C.I , Huang, Y.W. and Lin, Y. (1998). Tannins and Human Health: A Review. Critical Reviews in Food Science and Nutrition 38: 421-464.

Elsheikh, A.O., Nour, E.A.M. and Elkhalifa, A.O. (2014). Effect of storage on the quality attributes of concentrates of two mango (Mangifera indica) varieties grown in Sudan. British Journal of Applied Science and Technology 4(14): 2069-2078.

FAO. (2002). Mango, post-harvest operations. Fao.org. AGSI/FAO. Data accessed on 5 Feb, 2017.

FAO. (2006). Food and Agricultural Organization, Production Year Book, Food and Agricultural Organization, Rome, Italy.

Fowomola, M.A. (2010). Some nutrients and antinutrients contents of mango (Magnifera indica) seed. African Journal of Food Science 4(8): 472-476.
Goswami, T.K. Nath, A., Mangaraj S., Chauhan J. (2015). Post harvest management and production of important horticultural crops. Scientific Publishers, India, $436 \mathrm{p}$.

Gouado, I., Schweigert, F.J., Ejoh, R.A., Tchouanguep, M.F. and Camp, J.V. (2007). Systemic levels of carotenoids from mangoes and papaya consumed in three forms (juice, fresh and dry slice). European Journal of Clinical Nutrition 61(10): 1180-1188.

Ihekoronye, A.I. and Ngoddy, P.O. (1985). Integrated food science and technology for the tropics. Ma c milla Publisher Ltd London 386pp.

Islam, Md. K., Khan, M.Z.H., Sarkar, M.A.R., Absar, N. and Sarkar, S. K. (2013). Changes in acidity, TSS, and sugar content at different storage periods of the postharvest mango (Mangifera indica L.) influenced by Bavistin DF," International Journal of Food Science 2013: 8pp.

Kårlund, A., Moor, U., Mari, S. M. and Karjalainen, R.O. (2014). The impact of harvesting, storage and processing factors on health-promoting phytochemicals in berries and fruits. Processes 2: 596-624.

Lee, S.K. and Kader, A.A. (2000). Preharvest and postharvest factors influencing vitamin Ccontent of horticultural crops. Postharvest Biology Technology 20: 207-220.

Leghari, M.H., Sheikh, S.A., Kumbhar, M.B. and Baloch, A.F. (2013). Mineral Content in Dehydrated Mango Powder. Journal of Basic \& Applied Sciences, 9: 21-25

Lemmens, L., Tchuenche, E.S., Loey, A.M.V. and Hendrickx, M.E. (2013). Beta carotene isomerisation in mango puree as influenced by thermal processing and high pressure homogenization. European Food Research Technology 236: 155-163.

Londoño, M.B.Z., Chaparro D., Rojano, B.A., Arbelaez, A.F.A., Betancur L.F. and Celis, M.E.M. (2017). Effect of storage time on physicochemical, sensorial, and antioxidant characteristics, and composition of mango (cv. Azúcar) juice. Emirate Journal of Food and Agriculture 29(5): 367-377.

Maga, J.A. (1982). Phytate Its Chemistry: Occurrence, food interactions, nutritional Significance and Method of Analysis. Journal of Agriculture and Food Chemistry 30 (1): 1-9.

Masibo, M. and He, Q. (2009): Mango bioactive compounds and related nutraceutical properties-a review. Food Research International 25: 346-370.

Nielsen, S.S. (1998). Food Analysis 2nd Ed. Aspen Publishers.

Okwu, D.E. (2004). Phytochemicals and vitamin contents of indigenous species of South Eastern Nigeria. Journal of Sustainable Agriculture and the Environment 6:3034.

Price, K.R., Johnson I.T. and Fenwick, G.R. (1987). The chemistry and biological significance of saponins in foods and feeding stuffs. CRC Critical Reviews in Food Science and Nutrition 26(1): 1-7.

Ranganna, S.P.D. (2001). Handbook of analysis and quality control of fruit and vegetable products. New Delhi, Tata Mc Graw Hill.

Singh, N.I., Dhuique-Mayer, C., Lozano Y. (2000). Physico- 
chemical changes during enzymatic liquefaction of mango pulp (cv. Keitt). Journal of Food Processing and Preservation 24(1):73-85.

Slavin, J.L. and Lloyd, B. (2012). Health benefits of fruits and vegetables. Advances in Nutrition 3: 506-516.

SPSS. (2006). Statistical Package for Social Sciences. Version 15.0 for Windows, SPSS Inc. 2335, Walker Drive, Chicago, Illinois 60606.

Uddin, M.S., Hawlader, M.N.A., Ding, L. and Mujumdar, A.S. (2002). Degradation of ascorbic acid in dried guava during storage. Journal of Food Engineering 51: 21-26.

Wilson, R.A. Kadam, D.M.., Chadha, S. Grewal, M.K. and Sharma, M. (2014). Evaluation of physical and chemical properties of foam mat dried mango powder during storage. Journal of Food Processing and Preservation 38: 1866-1874. 